\section{Container Production of Southern Highbush Blueberries Using High Tunnels}

\author{
Tongyin $\mathrm{Li}^{\mathbf{1}}$ and Guihong Bi \\ Department of Plant and Soil Sciences, Mississippi State University, \\ Mississippi State, MS 39762
}

Additional index words. Vaccinium, fertilization, organic, yield, fruit quality

\begin{abstract}
Blueberry production in Mississippi (MS) is mainly rabbiteye blueberries (Vaccinium virgatum Ait.), which ripen in late May to June. Growing early-ripening southern highbush blueberries (SHBs) (Vaccinium corymbosum L.) presents an opportunity for early fruit production and increased market price for locally produced blueberries, yet faces the challenge of spring frost damage. One-year-old liners of $10 \mathrm{SHB}$ cultivars were transplanted into 15 -gallon plastic containers and placed in a high tunnel in Apr. 2015. Blueberry plants were fertilized with either a conventional or an organic fertilizer at comparable rates. Plants were evaluated for berry yield, timing of first berry harvest and peak harvest, single berry weight, and soluble solid content during the 2016 and 2017 growing seasons. The high tunnel increased monthly maximum temperature by 3.2 to $10.4{ }^{\circ} \mathrm{C}$, monthly average temperature by 0.7 to $4.2^{\circ} \mathrm{C}$, and minimum monthly temperature for up to $3.0{ }^{\circ} \mathrm{C}$ compared with outdoor environment. Photosynthetically active radiation $(P A R)$ at noon in the high tunnel ranged from 477 to $1411 \mu \mathrm{mol} \cdot \mathrm{m}^{-2} \cdot \mathrm{s}^{-1}$ and relative humidity ranged from $54.6 \%$ to $81.7 \%$ from Jan. 2016 to June 2017. SHBs in the high tunnel produced first berry harvest during the first week of April in both growing seasons. Total berry yield per plant ranged from $921 \mathrm{~g}$ to $2136 \mathrm{~g}$ in 2016 and from $1222 \mathrm{~g}$ to $2480 \mathrm{~g}$ in 2017 . Compared with the organic fertilizer, conventional fertilizer increased berry yield in April and May, and total berry yield in 2016, but resulted in similar yield in 2017. Eight cultivars (Emerald, Farthing, Gupton, Meadowlark, Pearl, Rebel, Star, and Sweetcrisp) produced single berries that averaged more than 2 g per berry in 2016, compared with two cultivars (Gupton and Pearl) in 2017. Smaller berry size may have resulted from the generally increasing yield from 2016 to 2017. 'Sweetcrisp' produced berries with higher soluble solid content, $14.2 \%$ and $14.1 \%$ in 2016 and 2017, than the other nine cultivars. Container production of SHB cultivars in a high tunnel produced total berry yield equivalent to $6458 \mathrm{~kg} / \mathrm{ha}$ in 2016 to $7500 \mathrm{~kg} / \mathrm{ha}$ in 2017, advanced blueberry production by 4 to 5 weeks, and therefore may serve as a potential production system for early fruiting blueberries in Mississippi.
\end{abstract}

Blueberry (Vaccinium spp.) is an important small fruit crop in the United States. The United States leads world blueberry production, producing 588.8 million pounds of cultivated blueberries in 2016 and a total crop value of $\$ 720.2$ million (Agricultural Marketing Resource Center, 2018). Thirtyeight states have commercial blueberry production, with the top 10 producing states

Received for publication 5 Oct. 2018. Accepted for publication 26 Nov. 2018.

This work was supported by Mississippi Department of Agriculture and Commerce Specialty Crop Block Grant Program and the United States Department of Agriculture (USDA) National Institute of Food and Agriculture Hatch project MIS-249180.

The authors thank McGeary Organics, Lancaster, PA, for the support on organic fertilizer.

Mention of a trademark, proprietary product, or vendor does not constitute a guarantee or warranty of the product by Mississippi State University or the USDA and does not imply its approval to the exclusion of other products or vendors that also may be suitable.

${ }^{1}$ Corresponding author. E-mail: t1665@msstate. edu.

HortScience Vol. 54(2) February 2019 is mainly located in southern Mississippi (south of interstate 20 toward the Gulf Coast) in USDA hardiness zones $8 \mathrm{a}, 8 \mathrm{~b}$, and $9 \mathrm{a}$.
Most blueberry production in Mississippi is rabbiteye blueberries (Stafne, 2015). Ripening period of rabbiteye blueberries falls into peak domestic blueberry production from late May to July with some of the lowest market pricing (Evans and Ballen, 2014). Production of early-ripening southern highbush blueberries (SHBs) presents an opportunity to increase market price significantly for the fresh blueberry market. Southern highbush cultivars generally require chilling hours of 200 to 700 and have low tolerance for freezing temperatures during flowering and fruiting (Fang et al., 2017; Retamales and Hancock, 2012; Rieger, 2006). The early blooming and ripening habit of southern highbush cultivars increases their exposure to late winter and early spring frost damage and can be challenging to grow in Mississippi. A high tunnel, an economic seasonextension tool, may provide frost protection for SHBs and promote production of early fruiting blueberries toward cooler zones.

High tunnels, also known as hoop houses, are constructed with metal or wooden ribs covered with polyethylene film. They do not have automatic heating or cooling systems, and rely on passive solar radiation and ventilation to increase temperature in the tunnel (Lamont, 2009; Lamont et al., 2002; Wells, 1996). High tunnels extend the growing season into late fall and early spring by increasing temperature for crop growth (Kadir et al., 2006; Lamont, 2009). The extended growing season with increased frost-free days can offer growers considerable market edge for off-season crops (Kadir et al., 2006). Strawberries (Fragaria xananassa Duch.) can be harvested 2 to 4 weeks earlier in high tunnels than open-field conditions (Jett, 2007; Kadir et al., 2006; Rowley et al., 2010). High tunnels were reported to advance flower initiation of southern highbush blueberry 'Emerald' and 'Jewel' over 30 d (Ogden and van Iersel, 2009). High tunnels also enabled early planting of raspberries (Rubus idaeus L.) and blackberries (Rubus spp.), produced higher yield, and increased marketable fruit by $82 \%$ to $98 \%$ (Kadir et al., 2006; Yao and Rosen, 2011). High tunnel production of small fruit in the United States has most acreages in raspberry and strawberry, with more applications in blueberry in Spain, Italy, and Mexico (Bañados, 2009; Ciordia et al., 2002; Demchak, 2009).

Container blueberry production using soilless substrate is a relatively new approach with increasing interest in recent years (Fulcher et al., 2015; Voogt et al., 2014). Blueberries have soil $\mathrm{pH}$ requirement of 4.5 to 5.5 (Retamales and Hancock, 2012). Container production of blueberry offers the advantage of not being limited by suboptimal soil conditions in the open field and the ability to control substrate $\mathrm{pH}$, drainage, and organic matter (Kingston et al., 2017). Container production in limited space such as a high tunnel enables moving of plants and adjusting growing density based on plant growth (Whidden, 2008). Soilless substrate 
with a desirable acidic $\mathrm{pH}$, including composted pine bark, peatmoss, and coconut coir, were investigated to serve as possible growing substrates for nursery production of blueberry plants (Fang et al., 2017; Kingston et al., 2017). The concerns of container production include potential constraint on root growth and the unknown feasibility of longterm production (Whidden, 2008). Shallow root systems of blueberries require sufficient irrigation to support plant growth and fruit development (Williamson et al., 2015). To date, there are few reports investigating container blueberry production, less in a high tunnel growing system.

The increased blueberry production worldwide has outpaced demand in recent years, resulting in lowered wholesale prices of blueberry; however, the market for organic blueberry is increasing (Julian et al., 2011; Strik et al., 2015, 2016). Certified organic blueberry production area in the United States increased from an estimated 19 ha in 2003 to 1,665 ha in 2011 (Strik, 2014). Organically produced blueberries often have a price premium of $20 \%$ to $100 \%$ compared with conventionally produced blueberries (DeVetter et al., 2015; Strik et al., 2017). There is an increasing interest in locally and organically produced fruits and vegetables driven by consumer health consciousness (Strik et al., 2016). Organically produced fruits and vegetables were shown to have increased levels of polyphenols compared with conventional produce (Asami et al., 2003; Carbonaro et al., 2002; Weibel et al., 2000; Zhao et al., 2007). The feasibility of container production of SHB cultivars, fertilized conventionally or organically, using a high tunnel requires investigation. Therefore, the objectives of this study were as follows: 1) to investigate yield performance and timing of fruit production of 10 southern highbush blueberry cultivars grown in containers using a high tunnel system; and 2) compare yield and quality of blueberries fertilized conventionally and organically

\section{Materials and Methods}

Plant cultivation and management. Two hundred 1-year-old liners of 10 southern highbush blueberry cultivars (Emerald, Farthing, GA Dawn, Gupton, Jewel, Meadowlark, Pearl, Rebel, Star, and Sweetcrisp) were transplanted into 15-gallon plastic containers on 8 Apr. 2015. Composted pine bark was used as growing substrate. Half of the blueberry plants were fertilized with a conventional slow-release fertilizer Osmocote Plus 15N-3.9P-10K (15-9-12, 8-9 months; Scotts Miracle-Grow Co., Marysville, $\mathrm{OH}$ ) at a rate of $120 \mathrm{~g}$ per plant based on a recommended medium rate and the other half was fertilized with an organic fertilizer $5 \mathrm{~N}-$ 1.3P-3.3K (5-3-4; McGeary Organics, Lancaster, PA) at a rate of $360 \mathrm{~g}$ per plant. Conventional fertilizer was applied twice a year in February at early blooming and in late June after fruit harvest. Due to low nutrient release rate from organic fertilizer (Ogden and van Iersel, 2009), organic fertilizer was applied three times a year: in February, late June, and late July. All plants were drip irrigated as needed. All containerized plants were placed under a high tunnel in zigzagged double rows of $0.76 \mathrm{~m}$ apart centerto-center and $0.61 \mathrm{~m}$ between rows. The high tunnel was located at the R.R. Foil Plant Science Research Center at Mississippi State University (lat. $33.45^{\circ} \mathrm{N}$, long. $88.79^{\circ} \mathrm{W}$ ) in USDA hardiness zone $8 \mathrm{a}$. The high tunnel was $29.0 \mathrm{~m}$ long by $9.1 \mathrm{~m}$ wide, placed in full sun, and oriented north to south (Tubular Structure, Mobil, AL). The high tunnel was covered with 6-mL clear plastic film and had side curtains (opens to $1.5 \mathrm{~m}$ high) and doors (opens up to $3 \mathrm{~m}$ high). Landscape fabric was used on the ground in the high tunnel for weed control. The doors and curtains of the tunnel were closed when local outdoor air temperature was lower than $4.4{ }^{\circ} \mathrm{C}$. Two bumblebee hives (Natupol; ARBICO Organics, Tucson, AZ) were introduced into the high tunnel in January and March to facilitate pollination in each growing season.

Environmental conditions. A data logger (HOBO Micro Station H21-002; Onset Computer Corp., Bourne, MA) was installed in the center of the high tunnel at the height of $1.2 \mathrm{~m}$. A temperature and relative humidity sensor (HOBO S-THB-M002; Onset Computer Corp.) and a quantum sensor (HOBO SLIA-M003; Onset Computer Corp.) were connected to the data logger to monitor air temperature, relative humidity, and photosynthetically active radiation $(P A R)$ at 1 -hour intervals. Local outdoor air temperature data were obtained from the Web site of USDANatural Resources Conservation Service (USDA-NRCS, 2018). Monthly growing degree days (GDDs) were estimated by (monthly average temperature - base temperature) $\times$ the number of days in a month. The base temperature used for SHBs was $7{ }^{\circ} \mathrm{C}$ (Kovaleski et al., 2015).

Berry harvest and data collection. Southern highbush cultivars were evaluated for the date of first harvest, berry yield, single berry weight, and soluble solid content for two growing seasons in 2016 to 2017. Ripe berries were harvested on a weekly basis when available. The date of first berry harvest for each plant was recorded. Fresh weight of berries from each plant was recorded at each harvest. Total berry yield per plant was calculated by summing berry yield from each harvest for each plant. Average single berry weight was calculated by measuring the weight of randomly selected 50 berries and dividing by 50 at each harvest. Peak harvest was defined as the highest berry harvest from each plant during a growing season. Date of peak harvest for each cultivar fertilized with a certain fertilizer type was defined as the date when most plants produced their peak harvest. Fruit soluble solid content was measured during peak production time using two to three ripe berries from each plant with a digital refractometer (PR-32 $\alpha$; ATATO USA, Bellevue, WA).
Experimental design. This experiment was conducted in a randomized complete block design in $2 \times 10$ factorial arrangement with two fertilizer types (conventional and organic) and 10 blueberry cultivars. Each treatment had five replications (blocks) and each replication contained two single-plant subsamples. Significance of main effects or the interaction among main factors was determined by analysis of variance (ANOVA) using the GLM procedure of SAS (version 9.4; SAS Institute, Cary, NC). Where indicated by ANOVA, means were separated by Tukey's honest significant difference at $P<0.05$. All statistical analyses were performed using SAS.

\section{Results}

Microenvironment in the high tunnel. Compared with ambient air temperature in Starkville, MS, the high tunnel raised monthly maximum air temperature by 3.2 to $10.4{ }^{\circ} \mathrm{C}$, average air temperature by 0.7 to $4.2{ }^{\circ} \mathrm{C}$, and minimum air temperature up to $3.0{ }^{\circ} \mathrm{C}$ (Fig. 1). The season-extension effect of high tunnels is attributed to the increased minimum temperature in late fall and early spring to reduce frost damage. From Jan. 2016 to June 2017, lowest outdoor temperatures occurred in Jan. $2016\left(-6.7^{\circ} \mathrm{C}\right)$, Dec. $2016 \quad\left(-5.0{ }^{\circ} \mathrm{C}\right)$, and Jan. 2017 $\left(-10.0{ }^{\circ} \mathrm{C}\right)$. The high tunnel resulted in monthly minimum temperature of $-4.2{ }^{\circ} \mathrm{C}$ in Jan. 2016, $-2.8{ }^{\circ} \mathrm{C}$ in Dec. 2016, and $-7.0^{\circ} \mathrm{C}$ in Jan. 2017. The major temperature differences introduced by the high tunnel were the elevated maximum temperature from Jan. 2016 to June 2017 and the increased monthly minimum temperature during the coldest months.

$P A R$ in the high tunnel at noon was less than $1000 \mu \mathrm{mol} \cdot \mathrm{m}^{-2} \cdot \mathrm{s}^{-1}$ in Jan., Feb., Nov., and Dec. 2016 and in Jan., Feb., and Mar. 2017 (Fig. 2A). PAR ranged from 1087 (Oct. 2016 ) to $1411 \mu \mathrm{mol} \cdot \mathrm{m}^{-2} \cdot \mathrm{s}^{-1}$ (July 2016) in the high tunnel from March to October in 2016, and from April to June 2017. Relative humidity in the high tunnel ranged from $54.6 \%$ in Jan. 2017 to $81.7 \%$ in Dec. 2016 (Fig. 2B).

Growing degree days. Due to elevated air temperature compared with the outdoor environment, the high tunnel accumulated 4751 GDDs in 2016 and 2066 GDDs from Jan. to June 2017, compared with 4183 and 1854 GDDs outdoors during the same time period, respectively (Table 1). The high tunnel accumulated higher monthly GDDs than outdoors by 19 to 129 GDDs from Jan. 2016 to June 2017. Higher differences of accumulated GDDs between high tunnel and outdoors occurred during colder months with 68 , 129 , and 71 GDDs higher in the high tunnel in Feb., Mar., and Dec. 2016. Compared with the outdoor environment, the high tunnel accumulated 568 more annual GDDs in 2016, and 212 more GDDs from Jan. to June 2017, totaling 780 from Jan. 2016 to June 2017.

Date of first berry harvest. In the first growing season, 'Georgia Dawn' and 'Meadowlark', 


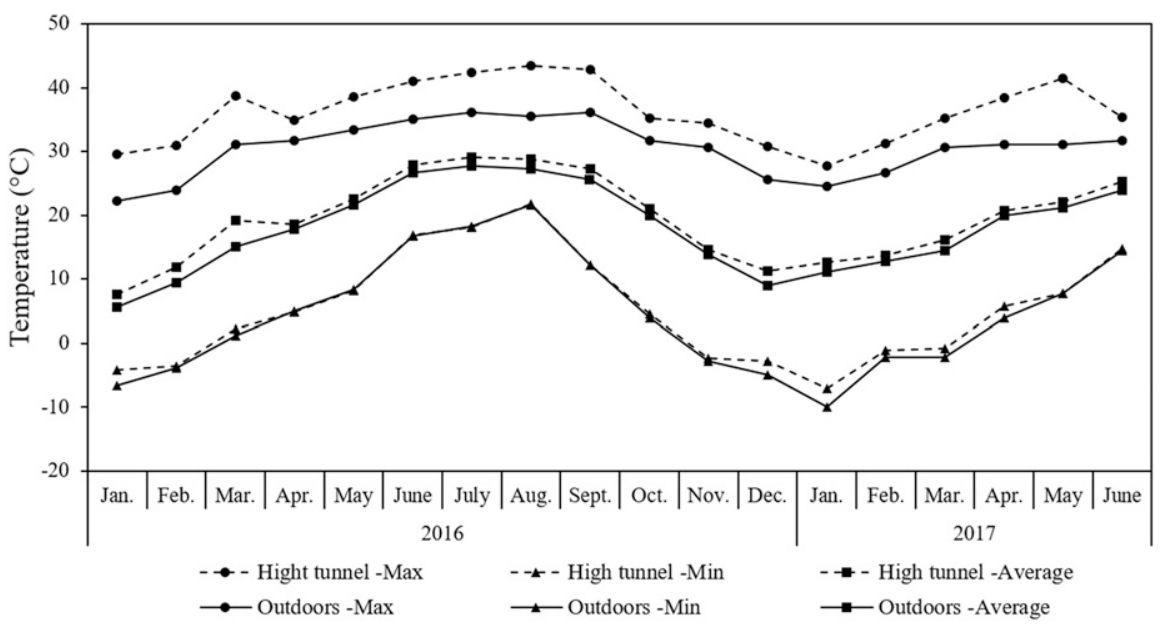

Fig. 1. Monthly maximum, average, and minimum air temperature in the high tunnel and outdoors. Air temperature in the high tunnel was recorded by a temperature and relative humidity sensor (HOBO S-THB-M002; Onset Computer Corp.). Local outdoor air temperature data were obtained from the U.S. Department of Agriculture-Natural Resources Conservation Service Web site.
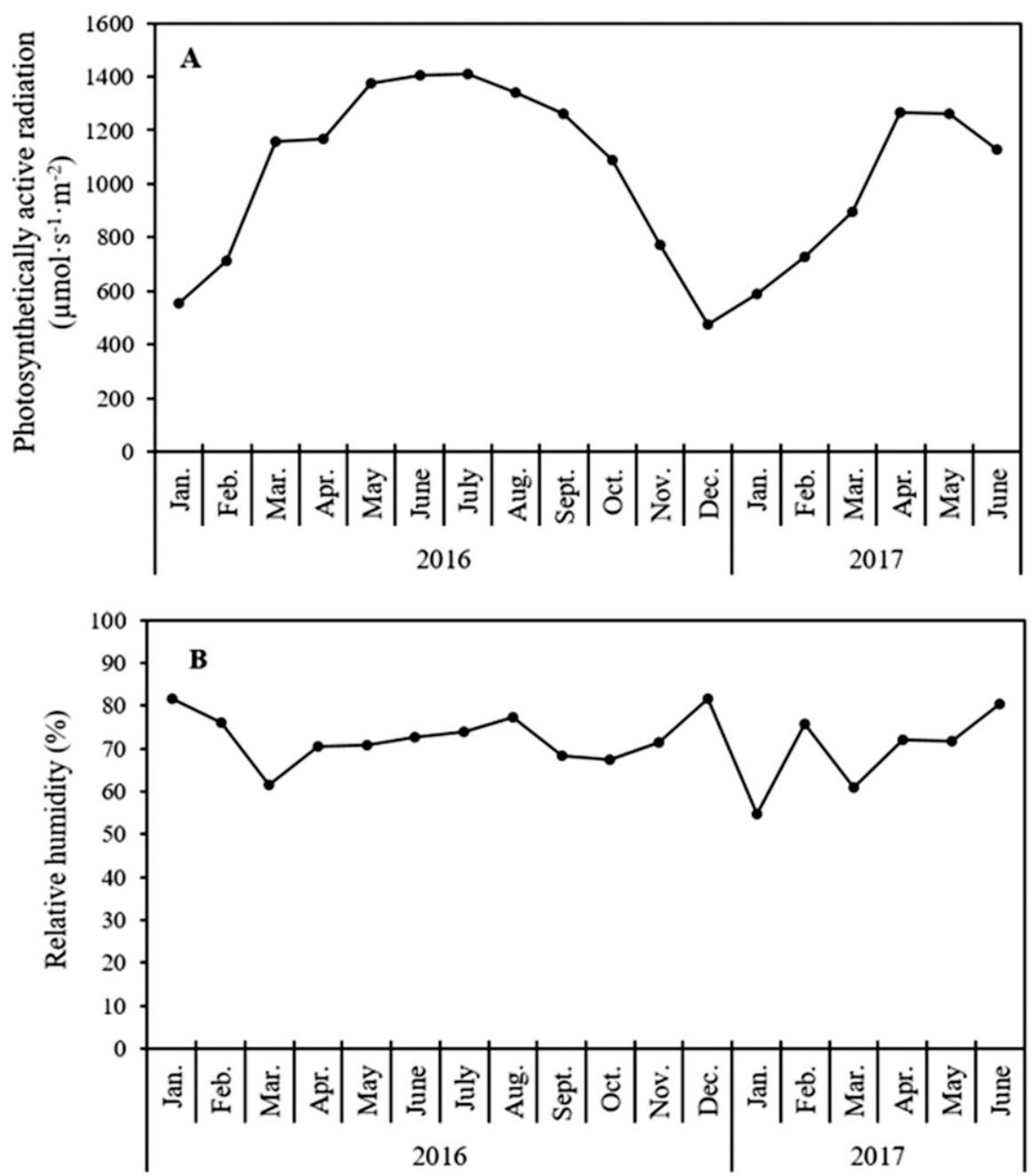

Fig. 2. Photosynthetically active radiation $(P A R)$ at noon averaged over a month and monthly average relative humidity in the high tunnel. PAR (A) and relative humidity $(\mathbf{B})$ in the high tunnel were recorded by a quantum sensor (HOBO S-LIA-M003; Onset Computer Corp.) and a temperature and relative humidity sensor (HOBO S-THB-M002; Onset Computer Corp.), respectively. Both sensors were connected to a data logger (HOBO Micro Station H21-002; Onset Computer Corp.).

conventionally or organically fertilized, and conventional fertilized 'Rebel' had their first berry harvest during the first week of April on
6 Apr. 2016 (Table 2). Conventionally fertilized 'Emerald', 'Farthing', 'Star', and 'Sweetcrisp', and organically fertilized 'Rebel' produced their first harvest on 14 Apr. 2016. Organically fertilized 'Emerald', 'Farthing', 'Star', and 'Sweetcrisp'; conventionally fertilized 'Gupton' and 'Pearl'; and conventionally or organically fertilized 'Jewel' produced their first harvest on 22 Apr. 2016. Organically fertilized 'Gupton' and 'Pearl' produced their first harvest on $29 \mathrm{Apr}$. 2016.

During the 2017 growing season, conventionally or organically fertilized 'Georgia Dawn', 'Emerald', 'Meadowlark', and 'Rebel'; and conventionally fertilized 'Farthing' produced their first berry harvest during the first week of April on 7 Apr. 2017 (Table 2). Conventionally fertilized 'Star' and organically fertilized 'Farthing' produced their first berry harvest on 13 Apr. 2017. Conventionally or organically fertilized 'Jewel', 'Sweetcrisp', and 'Pearl', conventionally fertilized 'Gupton', and organically fertilized 'Star' produced their first berry harvest on 20 Apr. 2017. Organically fertilized 'Gupton' produced first berry harvest on 28 Apr. 2017.

Peak harvest. In 2016, conventionally or organically fertilized 'Georgia Dawn' and organically fertilized 'Meadowlark' produced their earliest peak harvests from 22 to 29 Apr. 2016 (Table 2). Conventionally or organically fertilized 'Emerald', 'Jewel', 'Rebel', and 'Star'; conventionally fertilized 'Farthing' and 'Meadowlark'; and organically fertilized 'Sweetcrisp' produced peak harvests on 13 May. Conventionally or organically fertilized 'Gupton' and 'Pearl', conventionally fertilized 'Sweetcrisp', and organically fertilized 'Farthing' produced peak harvests from 27 May to 3 June. Peak harvest yield ranged from $257.8 \mathrm{~g}$ to $623.7 \mathrm{~g}$ berries per plant. The lowest peak harvest was produced by 'Georgia Dawn' and the highest was produced by 'Pearl', both fertilized conventionally.

In 2017, conventionally or organically fertilized 'Georgia Dawn', 'Meadowlark', 'Rebel', and 'Sweetcrisp', and organically fertilized 'Emerald' and 'Star' produced the earliest peak harvests on 28 Apr. 2017. Organically fertilized 'Farthing' and conventionally fertilized 'Star' produced peak harvest on 4 May and 11 May, respectively. Conventionally or organically fertilized 'Jewel' and 'Pearl', and conventionally fertilized 'Emerald' produced peak harvests on 18 May, with conventionally or organically fertilized 'Gupton' and conventionally fertilized 'Farthing' producing the latest peak harvests on 5 June. Peak harvest yield ranged from $380.5 \mathrm{~g}$ berries per plant in conventionally fertilized 'Sweetcrisp' to $704.4 \mathrm{~g}$ berries per plant in conventionally fertilized 'Meadowlark'.

Blueberry yield. There were a total of 12 berry harvests during the growing season 2016, from 6 Apr. to 1 July 2016. Total berry yield of 'Farthing', 'Gupton', 'Jewel', 'Meadowlark', 'Pearl', 'Rebel', and 'Sweetcrisp' in 2016 was comparable, ranging from $1708 \mathrm{~g}$ to $2136 \mathrm{~g}$ berries per plant (Fig. 3). 'Meadowlark' produced the highest yield in 
Table 1. Monthly growing degree days (GDDs) accumulated in the high tunnel and local outdoors.

\begin{tabular}{|c|c|c|c|c|c|c|}
\hline \multirow[b]{2}{*}{$\mathrm{Yr}$} & \multirow[b]{2}{*}{ Month } & \multirow[b]{2}{*}{ No. of days in the month } & \multicolumn{2}{|c|}{ High tunnel $^{\mathrm{z}}$} & \multicolumn{2}{|c|}{ Outdoors $^{y}$} \\
\hline & & & Monthly avg temp. $\left({ }^{\circ} \mathrm{C}\right)$ & Monthly GDDs & Monthly avg temp. $\left({ }^{\circ} \mathrm{C}\right)$ & Monthly GDDs \\
\hline 2016 & January & 31 & 7.6 & 19 & 5.6 & 0 \\
\hline 2016 & February & 29 & 11.8 & 139 & 9.4 & 71 \\
\hline 2016 & March & 31 & 19.2 & 377 & 15.0 & 248 \\
\hline 2016 & April & 30 & 18.6 & 348 & 17.8 & 323 \\
\hline 2016 & May & 31 & 22.4 & 479 & 21.7 & 455 \\
\hline 2016 & June & 30 & 27.8 & 625 & 26.7 & 590 \\
\hline 2016 & July & 31 & 29.1 & 685 & 27.8 & 644 \\
\hline 2016 & August & 31 & 28.8 & 677 & 27.2 & 627 \\
\hline 2016 & September & 30 & 27.3 & 608 & 25.6 & 557 \\
\hline 2016 & October & 31 & 21.1 & 436 & 20.0 & 403 \\
\hline 2016 & November & 30 & 14.6 & 228 & 13.9 & 207 \\
\hline 2016 & December & 31 & 11.2 & 129 & 8.9 & 59 \\
\hline 2017 & January & 31 & 12.6 & 172 & 11.1 & 127 \\
\hline 2017 & February & 28 & 13.7 & 188 & 12.8 & 162 \\
\hline 2017 & March & 31 & 16.1 & 281 & 14.4 & 231 \\
\hline 2017 & April & 30 & 20.7 & 410 & 20.0 & 390 \\
\hline 2017 & May & 31 & 22.0 & 465 & 21.1 & 437 \\
\hline 2017 & June & 30 & 25.3 & 550 & 23.9 & 507 \\
\hline
\end{tabular}

${ }^{\mathrm{z}}$ Monthly GDDs were calculated as GDDs $=\left(\mathrm{T}_{\text {monthly average }}-\mathrm{T}_{\text {base }}\right) \times$ number of days in a month. $\mathrm{T}_{\text {base }}=7{ }^{\circ} \mathrm{C}$ for southern highbush blueberries

${ }^{\mathrm{y}}$ Local outdoor air temperature data were obtained from the website of U.S. Department of Agriculture-Natural Resources Conservation Service.

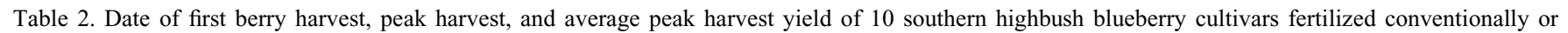
organically grown in a high tunnel.

\begin{tabular}{|c|c|c|c|c|c|c|c|}
\hline \multirow[b]{2}{*}{ Cultivar } & \multirow[b]{2}{*}{ Fertilizer $^{2}$} & \multicolumn{2}{|c|}{ Date of first harvest } & \multicolumn{2}{|c|}{ Date of peak harvest ${ }^{\mathrm{y}}$} & \multicolumn{2}{|c|}{ Peak harvest yield (g per plant) } \\
\hline & & 2016 & 2017 & 2016 & 2017 & 2016 & 2017 \\
\hline \multirow[t]{2}{*}{ Emerald } & Conventional & 14 Apr. & 7 Apr. & 13 May & 18 May & 417.6 & 615.0 \\
\hline & Organic & 22 Apr. & 7 Apr. & 13 May & 28 Apr. & 373.9 & 623.6 \\
\hline \multirow[t]{2}{*}{ Farthing } & Conventional & 14 Apr. & 7 Apr. & 13 May & 5 June & 551.3 & 559.5 \\
\hline & Organic & 22 Apr. & 13 Apr. & 3 June & 4 May & 404.0 & 571.7 \\
\hline \multirow[t]{2}{*}{ Georgia Dawn } & Conventional & 6 Apr. & 7 Apr. & 22 Apr. & 28 Apr. & 257.8 & 581.3 \\
\hline & Organic & 6 Apr. & 7 Apr. & 29 Apr. & 28 Apr. & 323.1 & 656.0 \\
\hline \multirow[t]{2}{*}{ Gupton } & Conventional & 22 Apr. & 20 Apr. & 27 May & 5 June & 487.9 & 503.3 \\
\hline & Organic & 29 Apr. & 28 Apr. & 27 May & 5 June & 411.2 & 515.7 \\
\hline \multirow[t]{2}{*}{ Jewel } & Conventional & 22 Apr. & 20 Apr. & 13 May & 18 May & 612.0 & 594.7 \\
\hline & Organic & 22 Apr. & 20 Apr. & 13 May & 18 May & 546.5 & 695.4 \\
\hline \multirow[t]{2}{*}{ Meadowlark } & Conventional & 6 Apr. & 7 Apr. & 13 May & 28 Apr. & 521.6 & 704.4 \\
\hline & Organic & 6 Apr. & 7 Apr. & 29 Apr. & 28 Apr. & 416.6 & 697.8 \\
\hline \multirow[t]{2}{*}{ Pearl } & Conventional & 22 Apr. & 20 Apr. & 27 May & 18 May & 623.7 & 543.9 \\
\hline & Organic & 29 Apr. & 20 Apr. & 27 May & 18 May & 486.0 & 463.8 \\
\hline \multirow[t]{2}{*}{ Rebel } & Conventional & 6 Apr. & 7 Apr. & 13 May & 28 Apr. & 485.8 & 391.4 \\
\hline & Organic & 14 Apr. & 7 Apr. & 13 May & 28 Apr. & 494.9 & 575.7 \\
\hline \multirow[t]{2}{*}{ Star } & Conventional & 14 Apr. & 13 Apr. & 13 May & 11 May & 398.4 & 669.8 \\
\hline & Organic & 22 Apr. & 20 Apr. & 13 May & 28 Apr. & 341.7 & 643.8 \\
\hline \multirow[t]{2}{*}{ Sweetcrisp } & Conventional & 14 Apr. & 20 Apr. & 27 May & 28 Apr. & 409.1 & 380.5 \\
\hline & Organic & 22 Apr. & 20 Apr. & 13 May & 28 Apr. & 437.2 & 413.3 \\
\hline
\end{tabular}

${ }^{\mathrm{z} B l u e b e r r y}$ plants were fertilized with a conventional fertilizer Osmocote Plus 15N-3.9P-10K (15-9-12, 8-9 months; Scotts Miracle-Grow Co., Marysville, OH) or an organic fertilizer $5 \mathrm{~N}-1.3 \mathrm{P}-3.3 \mathrm{~K}(5-3-4$, McGeary Organics, Lancaster, PA).

${ }^{\mathrm{y}}$ Date of peak harvest was defined as the date when the most plants of a certain cultivar fertilized conventionally or organically produced the highest harvest during one growing season.

April, averaging $719.6 \mathrm{~g}$ berries per plant. Among the early-ripening cultivars, 'Georgia Dawn' and 'Rebel' produced comparable yields of $533.3 \mathrm{~g}$ and $482.6 \mathrm{~g}$ berries per plant in April, respectively. Most tested cultivars had increasing yield in May compared with April, with eight cultivars producing their peak harvests in May. 'Farthing', 'Jewel', 'Rebel', and 'Sweetcrisp' produced comparable yields in May, ranging from $1218 \mathrm{~g}$ to $1543 \mathrm{~g}$ berries per plant, higher than the yield of 'Georgia Dawn' and 'Gupton', $387.3 \mathrm{~g}$ and $653.1 \mathrm{~g}$ berries per plant, respectively. Later in the season in June, the two late-season cultivars 'Gupton' and 'Pearl' produced the highest yield, averaging $1048 \mathrm{~g}$ and $843 \mathrm{~g}$ berries per plant, respectively. Conventional fertilizer increased berry yield compared with the or- ganic fertilizer in April and May, and increased total berry yield per plant in 2016 by $38.2 \%, 18.0 \%$, and $14.5 \%$, respectively (Table 3).

In 2017 , there were 11 berry harvests from 7 Apr. to 22 June. 'Emerald', 'Farthing', 'Jewel', 'Meadowlark', 'Rebel', and 'Star' produced comparable total berry yields ranging from $2000 \mathrm{~g}$ to $2480 \mathrm{~g}$ berries per plant, significantly higher than the yield of 'Pearl' (1222 g berries per plant) (Fig. 4). Total berry yields of 'Georgia Dawn', 'Gupton', and 'Sweetcrisp' were comparable, ranging from $1528 \mathrm{~g}$ to $1752 \mathrm{~g}$ berries per plant. Generally, monthly distribution of berry yield in the 2017 growing season shared a similar trend with 2016. Early in the season in April, 'Georgia Dawn' and 'Meadowlark' produced the highest yields, $1113 \mathrm{~g}$ and $1060 \mathrm{~g}$ berries per plant, respectively, higher than the other eight cultivars. Lower than 'Georgia Dawn' and 'Meadowlark', 'Emerald', 'Rebel', and 'Star' produced comparable yields, ranging from $609.4 \mathrm{~g}$ to $777.9 \mathrm{~g}$ berries per plant, but higher than yields of 'Gupton' or 'Pearl'. In May, 'Emerald', 'Jewel', 'Meadowlark', and 'Star' produced comparable yields, ranging from $1374 \mathrm{~g}$ to $1772 \mathrm{~g}$ berries per plant, higher than 'Georgia Dawn' or 'Pearl'. In June, 'Farthing' and 'Gupton' produced comparable yields, $497.8 \mathrm{~g}$ and $561.5 \mathrm{~g}$ berries per plant, respectively, higher than any other cultivars. Fertilizer type did not affect berry yield in 2017.

Single berry weight. Single berry weight data were presented only in early May in both growing seasons during peak production time when all cultivars were producing berries. 


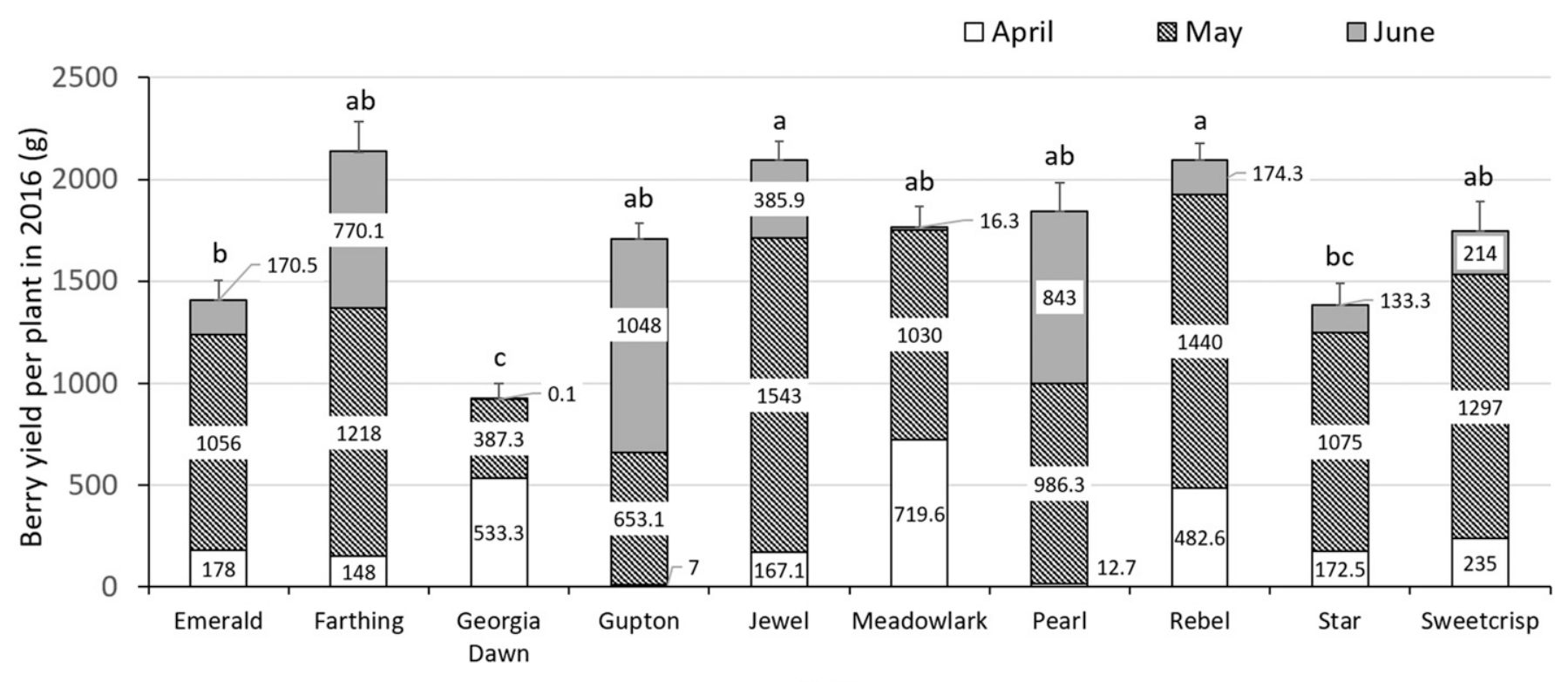

\section{Cultivar}

Fig. 3. Blueberry yield in April, May, and June, and total berry yield per plant of 10 southern highbush blueberry cultivars grown in a high tunnel in the 2016 growing season. Means for a certain cultivars were obtained over two fertilizer types. Different lower-case letters on a certain bar suggest significant difference in total berry yield per plant indicated by Tukey's honest significant difference test at $P<0.05$. Error bars suggest SE of total berry yield per plant in 2016 .

Table 3. Blueberry yield in April, May, and June, and total berry yield of southern highbush blueberries grown in a high tunnel affected by fertilizer type in 2016.

\begin{tabular}{lcccc}
\hline & \multicolumn{3}{c}{ Berry yield in 2016 (g per plant) } \\
\cline { 2 - 5 } Fertilizer $^{z}$ & April & May & June & Total \\
\hline Conventional & $308.1 \mathrm{a}$ & $1157 \mathrm{a}$ & 360.6 & $1826 \mathrm{a}$ \\
Organic & $223.0 \mathrm{~b}$ & $979.7 \mathrm{~b}$ & 390.5 & $1593 \mathrm{~b}$ \\
$P$ value $^{\mathrm{y}}$ & $<0.0001$ & 0.0003 & 0.35 & 0.0006 \\
\hline${ }^{\mathrm{z}}$ Blueberry plants were fertilized with a conventional \\
fertilizer Osmocote Plus $15 \mathrm{~N}-3.9 \mathrm{P}-10 \mathrm{~K}$ (15-9-12, \\
$8-9$ months; Scotts Miracle-Grow Co., Marys- \\
ville, OH) or an organic fertilizer 5N-1.3P- \\
$3.3 \mathrm{~K}$ (5-3-4, McGeary Organics, Lancaster, \\
PA). \\
${ }^{\mathrm{y}}$ Means for a certain fertilizer were obtained over \\
10 blueberry cultivars. Different lower-case letters \\
within a column suggest significant difference \\
indicated by Tukey's honest significant difference \\
test at $P<0.05$.
\end{tabular}

'Pearl' produced the largest berry in 2016 and 2017, averaging 2.6 and 2.48 g per berry, respectively (Table 4). In 2016, 'Emerald', 'Farthing', 'Gupton', 'Meadowlark', 'Rebel', 'Star', and 'Sweetcrisp' produced single berry weights greater than $2 \mathrm{~g}$ per berry. 'Georgia Dawn' and 'Jewel' produced the lowest single berry weight of 1.73 and $1.92 \mathrm{~g}$ per berry, respectively. In 2017, 'Gupton' produced the second largest berry, averaging $2.02 \mathrm{~g}$ per berry, with other eight cultivars producing berries ranging from $1.23 \mathrm{~g}$ to $1.94 \mathrm{~g}$ per berry. 'Georgia Dawn' produced the smallest berry, averaging $1.23 \mathrm{~g}$ per berry. Fertilizer type did not affect single berry weight in either growing season.

Berry soluble solid content (Brix\%). In both years, 'Sweetcrisp' produced berries with the highest soluble solid content, $14.2 \%$ and $14.1 \%$ in 2016 and 2017 , respectively (Table 4). In 2016, nine tested cultivars, other than 'Sweetcrisp' produced berries with similar soluble solid content, ranging from $10.6 \%$ to $12.1 \%$. In 2017 , 'Meadowlark' and 'Rebel' produced berries with the lowest soluble solid content of $9.6 \%$ and $9.7 \%$, respectively. These values were lower than soluble solid content in berries produced by 'Georgia Dawn', 'Gupton', or 'Pearl', and comparable to 'Emerald', 'Farthing', 'Jewel', and 'Star'. Fertilizer type did not affect berry soluble solid content in either growing season.

\section{Discussion}

The use of a high tunnel system was reported to advance flower bud initiation of SHBs for up to $39 \mathrm{~d}$ in Georgia (Ogden and van Iersel, 2009). In our study, the high tunnel advanced first berry harvest to the first week of April in both growing seasons. Blueberry harvest starting from early April was $\approx 4$ to 5 weeks more advanced than traditional open-field ripening of rabbiteye blueberries in Mississippi from late May to June. Advancement of southern highbush blueberry harvest by $9 \mathrm{~d}$ in April was considered valuable because it significantly increased market price of blueberries (NeSmith, 2008). The advancement of 4 to 5 weeks compared with field production of rabbiteye blueberries will introduce a tremendous increase in market price. In addition, the high tunnel used in our study produced a first berry harvest at a similar time of estimated first harvest date in cultivars such as 'Star' (used as a standard SHB cultivar, ripens from early to late April), 'Emerald', and 'Rebel' grown in hardiness zones $8 \mathrm{a}$ to $8 \mathrm{~b}$ in open-field conditions (Lyrene, 2008; Lyrene and Sherman, 2000; NeSmith, 2008). This trend also holds true for the extremely early-ripening cultivar 'Meadowlark' bringing its first harvest on Apr. 10 in Gainesville, FL (USDA hardiness zone 9a) (Florida Foundation Seed Producers, Inc., 2013).

Timing of fruit ripening in blueberries is related to a number of factors, including chilling, heat units (or GDDs), pollination, leaf development, and crop load (NeSmith, 2014a). GDDs have been used to predict blooming and fruit ripening of a number of horticulture crops, including blueberries (Gibson, 2011; Kirk and Isaacs, 2012; Kovaleski et al., 2015; White et al., 2012). Kovaleski et al. (2015) reported that southern highbush cultivar 'Emerald' required 225 GDDs for peak bloom (50\% bloom), whereas peak bloom of 'Jewel' occurred with 302 accumulated GDDs. Lowbush blueberries generally require 1200 to 1400 GDDs for fruit ripening (Gibson, 2011) and rabbiteye cultivars require 1300 to 1900 GDDs for fruit ripening with variances among cultivars (NeSmith, 2014a). GDDs requirement for blooming and fruit ripening might be species and cultivar dependent. Total length of fruit development period of SHBs generally ranges from 55 to $66 \mathrm{~d}$ (Retamales and Hancock, 2012). The high tunnel increased air temperature and monthly GDDs up to 129 degree days compared with outdoor environment in the current study. Increased GDDs in the high tunnel not only extended the growing season into early spring, advanced blooming, but also hastened fruit ripening of SHB cultivars. Further research investigating timing from flower bud initiation to blooming and fruit development in relation to GDDs and chilling requirement will assist in more accurately predicting fruit ripening in a high tunnel growing system. 
$\square$ April $\mathbb{Q}$ May $\square$ June

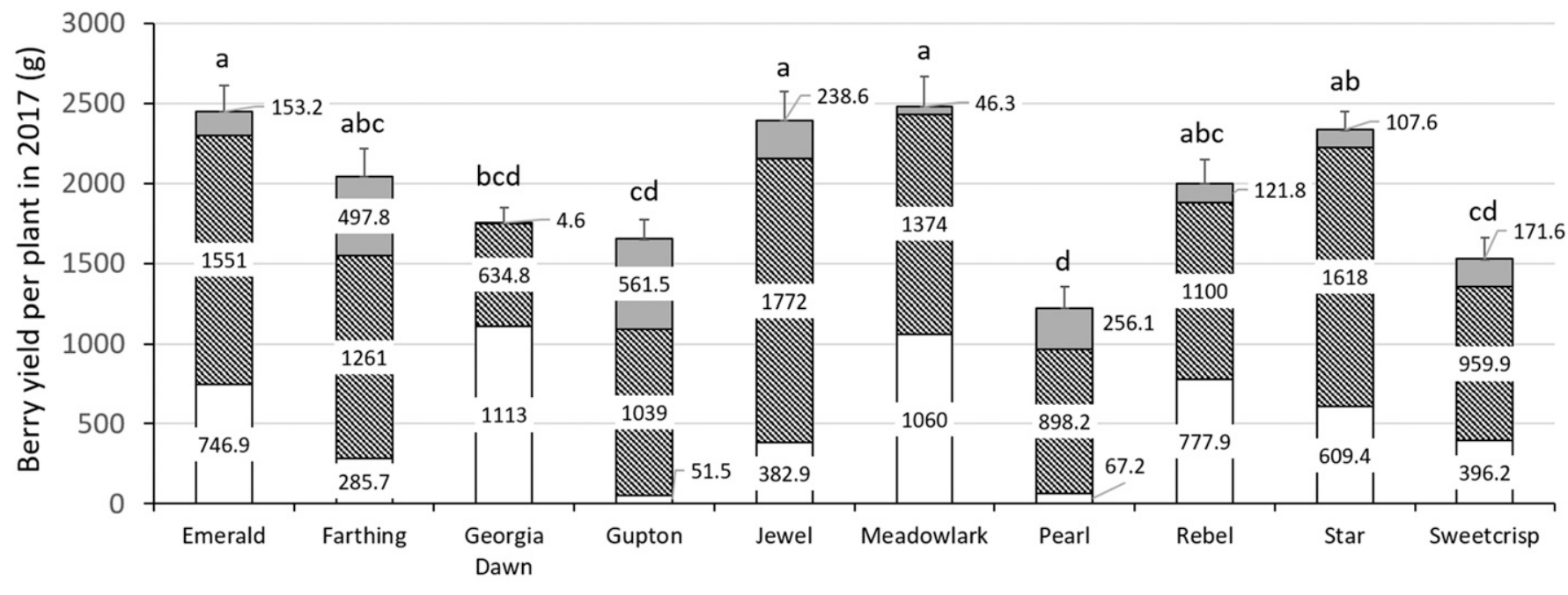

Cultivar

Fig. 4. Blueberry yield in April, May, and June, and total berry yield per plant of 10 southern highbush blueberry cultivars grown in a high tunnel in the 2017 growing season. Means for a certain cultivars were obtained over two fertilizer types. Different lower-case letters on a certain bar suggest significant difference in total berry yield per plant indicated by Tukey's honest significant difference test at $P<0.05$. Error bars suggest SE of total berry yield per plant in 2017.

Table 4. Average single berry weight and fruit soluble solid content of 10 southern highbush cultivars grown in a high tunnel in 2016 and 2017.

\begin{tabular}{|c|c|c|c|c|}
\hline \multirow[b]{2}{*}{ Cultivar } & \multicolumn{2}{|c|}{ Single berry wt $(\mathrm{g} \text { per berry })^{\mathrm{z}}$} & \multicolumn{2}{|c|}{ Fruit soluble solid content (Brix\%) } \\
\hline & 13 May 2016 & 11 May 2017 & 6 May 2016 & 4 May 2017 \\
\hline Emerald & $2.35 a b c$ & $1.94 \mathrm{bc}$ & $12.0 \mathrm{~b}$ & $10.5 \mathrm{bc}$ \\
\hline Farthing & $2.27 \mathrm{bcd}$ & $1.73 \mathrm{~cd}$ & $11.0 \mathrm{~b}$ & $10.4 \mathrm{bc}$ \\
\hline Georgia Dawn & $1.73 \mathrm{f}$ & $1.23 \mathrm{f}$ & $11.5 \mathrm{~b}$ & $11.2 \mathrm{~b}$ \\
\hline Gupton & $2.20 \mathrm{bcde}$ & $2.02 \mathrm{~b}$ & $11.4 \mathrm{~b}$ & $11.5 \mathrm{~b}$ \\
\hline Jewel & $1.92 \mathrm{ef}$ & $1.41 \mathrm{ef}$ & $11.7 \mathrm{~b}$ & $10.7 \mathrm{bc}$ \\
\hline Meadowlark & $2.38 \mathrm{ab}$ & $1.70 \mathrm{~cd}$ & $11.1 \mathrm{~b}$ & $9.6 \mathrm{c}$ \\
\hline Pearl & $2.60 \mathrm{a}$ & $2.48 \mathrm{a}$ & $11.8 \mathrm{~b}$ & $11.3 \mathrm{~b}$ \\
\hline Rebel & $2.31 \mathrm{abcd}$ & $1.56 \mathrm{de}$ & $10.6 \mathrm{~b}$ & $9.7 \mathrm{c}$ \\
\hline Star & $2.02 \mathrm{def}$ & $1.72 \mathrm{~cd}$ & $12.1 \mathrm{~b}$ & $10.6 \mathrm{bc}$ \\
\hline Sweetcrisp & $2.08 \mathrm{cde}$ & $1.80 \mathrm{bcd}$ & $14.2 \mathrm{a}$ & $14.1 \mathrm{a}$ \\
\hline$P$ value $^{\mathrm{y}}$ & $<0.0001$ & $<0.0001$ & $<0.0001$ & $<0.0001$ \\
\hline
\end{tabular}

${ }^{\mathrm{z}}$ Single berry weight was calculated by measuring the weight of 50 randomly selected berries and dividing by 50 .

${ }^{\mathrm{y}}$ Means for certain cultivars were obtained over two fertilizer types. Different lower-case letters within a column suggest significant difference indicated by Tukey's honest significant difference test at $P<0.05$.

Within the experiment's duration, lowest outdoor temperatures of $\approx-6.7^{\circ} \mathrm{C}$ occurred several times in Jan. and Feb. 2016, and once in Jan. 2017. During the three cold nights in Jan. 2016 (on 11 Jan., 19 Jan., and 24 Jan., respectively), outdoor minimum temperature dropped to -6.7 to $-5.6{ }^{\circ} \mathrm{C}$. The high tunnel maintained minimum temperatures of -3.9 to $-3.3{ }^{\circ} \mathrm{C}$ on those nights. Ogden and van Iersel (2009) reported that high tunnels did not provide freeze protection and had lower minimum temperature than the outdoor environment on a number of nights. They believed the fast radiative loss through the polyethylene film in the high tunnel may have contributed to the lower night temperatures. By comparison, the high tunnel used in the current study provided some frost protection by increasing minimum air temperature up to $3.0^{\circ} \mathrm{C}$. Reasons causing this difference might be the larger size of our high tunnel $(29.0 \times$ $9.1 \mathrm{~m})$, compared with the high tunnel $(12 \times$ $6 \mathrm{~m}$ ) used by Ogden and van Iersel (2009). In the Ogden and van Iersel (2009) study, the high tunnels were closed on a certain date and remained closed after. But in our study, the high tunnel was closed with night temperature of $4.4{ }^{\circ} \mathrm{C}$ or below, but stayed open during the day with temperature higher than $4.4{ }^{\circ} \mathrm{C}$. Opening on warm days probably increased heat accumulation during the day and helped increase minimum air temperature at night. In addition, the high planting density in the high tunnel might have slowed down the air circulation within the tunnel and radiative loss to the ambient environment. Frost protection from the high tunnel may be further improved by installing cost-efficient heaters, as suggested by Ogden and van Iersel (2009)

Blueberry flowers are increasingly susceptible to freeze damage as developmental stage progresses (Ogden and van Iersel, 2009). Flower buds can tolerate temperatures of -5 to $-4{ }^{\circ} \mathrm{C}$, while the plant is at its most vulnerable stage after petal fall with small developing berries when freeze injury can occur at $0{ }^{\circ} \mathrm{C}$ (Michigan State Univ. Extension, 2018). Blooming flowers and developing berries of 'Emerald', 'Rebel', and 'Meadowlark' were damaged by frost in 2016. There was no observable frost damage in 2017, possibly because most cultivars were at their early stages of flower and fruit development and less subjective to freezing temperatures. Blueberry 'Georgia Dawn' produced the earliest peak harvest in both growing seasons in late April, with the first berry harvest produced in early April. Flowering habit of 'Georgia Dawn' was late enough to avoid most freezing temperatures in January and February, but still produced the earliest peak berry harvests due to its shorter fruit development period. Such results are consistent with Kovaleski et al. (2015) that late-flowering habit can be a natural benefit for SHBs to avoid frost damage in early spring.

In the two growing seasons from 2016 to 2017 , total blueberry yield per plant averaged from $920.7 \mathrm{~g}$ for 'Georgia Dawn' in 2016 to $2480 \mathrm{~g}$ for 'Meadowlark' in 2017. Total yields in the high tunnel produced by all plants were $171 \mathrm{~kg}$ in 2016 and $199 \mathrm{~kg}$ in 2017. The high tunnel used in this study is equal to 0.026 ha of area. With traditional growing density of 1.2 to $1.8 \mathrm{~m}$ between plants and 2.4 to $3.7 \mathrm{~m}$ between rows, a hectare typically holds 2500 plants (Univ. of California, 2012). Arrangement of 200 plants in our high tunnel accounted for approximately three times the growing density of traditional field planting. Total yields of 2 - to 3 -year-old blueberry plants in our high tunnel were estimated to be $6458 \mathrm{~kg} / \mathrm{ha}$ and $7500 \mathrm{~kg} / \mathrm{ha}$ in 2016 and 2017, respectively. Even with some yield loss to frost damage in winter 2016, such yield was considered as satisfactory as yield in traditional field conditions 
during establishment years (Bluegrass Blueberries, 2018; Clemson Cooperative Extension, 2015). In addition, the advanced harvest by 4 to 5 weeks, can introduce significantly higher market prices and considerable profit margins for growers. Therefore, with significantly advanced fruit production, the high tunnel growing system using containerized SHBs may serve as a viable growing system for early fruiting blueberry production.

A potential concern with the high tunnel production system is its longevity. Containers may limit blueberry root growth at a certain age and may cause plants to decline. However, blueberries generally have shallow root systems, and plant growth and fruit production may be supported by providing sufficient fertilization and irrigation. Another concern is the cost of the high tunnel, with unit price ranging from $\$ 2.25$ to $\$ 5.00$ per square foot. A high tunnel of $30 \times 96 \mathrm{ft}$ typically costs $\$ 7000$ to $\$ 9000$, depending on tunnel features, including rollup sides, doors, steel thickness, and type of film (Robbins and $\mathrm{Gu}, 2018)$. The capital investment in high tunnels is typically recovered over 1 to 5 years, which can be justified by high market prices of off-season crops (O'Connell, 2012)

Eight cultivars produced berries higher than 2 g per berry in 2016, with two cultivars producing berries higher than $2 \mathrm{~g}$ per berry in 2017. Siefker and Hancock (1986) reported that there was an inverse relationship between berry size and the number of berries on blueberry. Increased flower bud density has a decreasing effect on blueberry fruit size and quality (Maust et al., 1999; Swain and Darnell, 2002). This trend might explain the generally increased total yield per plant from 2016 to 2017, and therefore smaller berries. The berry soluble solid content of tested SHB cultivars ranged from $10.6 \%$ to $14.2 \%$ and $9.6 \%$ to $14.1 \%$ in 2016 and 2017 , respectively, which fell into the normal range of southern highbush cultivars (NeSmith, 2014b; Ogden and van Iersel, 2009). Fertilizer type did not affect berry yield in 2017. The conventional fertilizer increased berry yield compared with organic fertilizer in April and May, and total berry yield per bush in 2016. Organic fertilizer delayed first berry harvest for 1 week in seven of the tested cultivars, which is possibly attributed to the low release rate of organic fertilizer. Reduced radiation in the high tunnel was found to reduce phenolic compounds in lettuce compared with open field, and differences varied among cultivars and growing seasons (Zhao et al., 2007). Blueberry quality in terms of health beneficial compounds and postharvest quality affected by cultivar, fertilizer type, and the high tunnel will be investigated in future research.

\section{Literature Cited}

Agricultural Marketing Resource Center. 2018. Blueberries. 24 Sept. $2018<\mathrm{https}$ ://www. agmrc.org/commodities-products/fruits/blueberries>.

Asami, D.K., Y.J. Hong, D.M. Barrett, and A.E. Mitchell. 2003. Comparison of the total phe- nolic and ascorbic acid content of freeze-dried and air-dried marionberry, strawberry, and corn grown using conventional, organic, and sustainable agricultural practices. J. Agr. Food Chem. 51:1237-1241.

Bañados, M.P. 2009. Expanding blueberry production into non-traditional production areas: Northern Chile and Argentina, Mexico and Spain. Acta Hort. 810:439-445.

Bluegrass Blueberries. 2018. Small Farm Business Opportunity-How to Profit from Blueberry Sales? 6 Sept. 2018. <http://bluegrassblueberries. $\mathrm{com} /$ small-farm-business-opportunity-how-toprofit-from-blueberry-sales/>

Carbonaro, M., M. Mattera, S. Nicoli, P. Bergamo, and M. Cappelloni. 2002. Modulation of antioxidant compounds in organic vs conventional fruit (peach Prunus persica L., and pear, Pyrus communis L.). J. Agr. Food Chem. 50:54585462.

Ciordia, M., M.B. Díaz, and J.C. García. 2002. Blueberry culture both in pots and under Italian-type tunnels. Acta Hort. 574:123127.

Clemson Cooperative Extension. 2015. Home \& Garden Information Center. Blueberry. Factsheet HGIC 1401. 6 Sept. 2018. <https://hgic. clemson.edu/factsheet/blueberry/>.

Demchak, K. 2009. Small fruit production in high tunnels. HortTechnology 19:44-49.

DeVetter, L.W., D. Granatstein, E. Kirby, and M. Brady. 2015. Opportunities and challenges of organic highbush blueberry production in Washington state. HortTechnology 25:796804.

Evans, E.A. and F.H. Ballen. 2014. An overview of US blueberry production, trade, and consumption, with special reference to Florida. Univ. of Florida. IFAS Extension FE952. 21 Aug. 2018. $<$ http://edis.ifas.ufl.edu/fe952>.

Fang, Y., J. Williamson, R. Darnell, Y. Li, and G. Liu. 2017. Nitrogen uptake and allocation at different growth stages of young southern highbush blueberry plants. HortScience 52:905-909.

Florida Foundation Seed Producers, Inc. 2013 Meadowlark ${ }^{\mathrm{TM}}$ 'FL01-173'. 6 Sept. 2018. <http:// www.ffsp.net/varieties/blueberry/meadowlarkfl01-173/>.

Fulcher, A., N.W. Gauthier, W.E. Klingeman, F. Hale, and S.A. White. 2015. Blueberry culture and pest, disease, and abiotic disorder management during nursery production in the southeastern US: A review. J. Environ. Hort. 33:33-47.

Gibson, L.D. 2011. Characterization of fruit development and ripening of Vaccinium angustifolium Ait. in relation to microclimatic conditions. Dalhousie Univ., Nova Scotia, MS Thesis.

Jett, L.W. 2007. Growing strawberries in high tunnels in Missouri. 21 Aug. 2018. <http:// hightunnels.org/wp-content/uploads/2013/06/ Growing_Strawberries_in_High_Tunnels.pdf $>$.

Julian, J., B. Strik, E. Pond, and W. Yang. 2011. Blueberry economics: Establishing and producing organic blueberries in the Willamette valley. Oregon State Univ. Extension Service. AEB 0023. 7 Sept. 2018. <http://arec. oregonstate.edu/oaeb/files/pdf/AEB0023.pdf>.

Kadir, S., E. Carey, and S. Ennahli. 2006. Influence of high tunnel and field conditions on strawberry growth and development. HortScience 41:329-335.

Kingston, P.H., C.F. Scagel, D.R. Bryla, and B. Strik. 2017. Suitability of sphagnum moss, coir, and Douglas fir bark as soilless substrates for container production of highbush blueberry. HortScience 52:1692-1699.

Kirk, A.K. and R. Isaacs. 2012. Predicting flower phenology and viability of highbush blueberry. HortScience 47:1291-1296.

Kovaleski, A.P., J.G. Williamson, J.W. Olmstead, and R.L. Darnell. 2015. Inflorescence bud initiation, development, and bloom in two southern highbush blueberry cultivars. J. Amer. Soc. Hort. Sci. 140:38-44.

Lamont, W.J. 2009. Overview of the use of high tunnels worldwide. HortTechnology 19:25-29.

Lamont, W.J., M. McGann, M. Orzolek, N. Mbugua, B. Dye, and D. Reese. 2002. Design and construction of the Penn State high tunnel. HortTechnoloy 12:447-453.

Lyrene, P.M. 2008. 'Emerald' southern highbush blueberry. HortScience 43:1606-1607.

Lyrene, P.M. and W.B. Sherman. 2000. 'Star' southern highbush blueberry. HortScience 35:956-957.

Maust, B.E., J.G. Williamson, and R.L. Darnell. 1999. Flower bud density affects vegetative and fruit development in field-grown southern highbush blueberry. HortScience 34:607610.

Michigan State Univ. Extension. 2018. Blueberries growth stages. 6 Sept. 2018. <https://www.canr. msu.edu/blueberries/growing_blueberries/ growth-stages $>$.

NeSmith, D.S. 2008. 'Rebel' southern highbush blueberry. HortScience 43:1592-1593.

NeSmith, D.S. 2014a. UGA Blueberry Blog. Rabbiteye blueberries 2014: When will they ripen? 6 Sept. 2018. <https://site.caes.uga.edu/blueberry/ 2014/05/rabbiteye-ripening-time/>.

NeSmith, D.S. 2014b. 'TH-819' Southern highbush blueberry Georgia Dawn ${ }^{\mathrm{TM}}$. HortScience 49:674-675.

O'Connell, S., C. Rivard, M.M. Peet, C. Harlow, and F. Louws. 2012. High tunnel and field production of organic heirloom tomatoes: Yield, fruit quality, disease, and microclimate. HortScience 47:1283-1290.

Ogden, A.B. and M.W. van Iersel. 2009. Southern highbush blueberry production in high tunnels: Temperature, development, yield, and fruit quality during the establishment years. HortScience 44:1850-1856.

Retamales, J.B. and J.F. Hancock. 2012. Blueberries. Crop production science in horticulture; no. 21. CABI, Cambridge, MA.

Rieger, M. 2006. Introduction to fruit crops. The Haworth Press, Binghamton, NY.

Robbins, J.A. and M. Gu. 2018. Cost of constructing a metal hoop high tunnel. Univ. of Arkansas. Agriculture and Natural Resources. FSA6147. 21 Nov. 2018. <https://www.uaex. edu/publications/PDF/FSA-6147.pdf>.

Rowley, D., B.L. Black, and D. Drost. 2010. Earlyseason extension using June-bearing 'Chandler' strawberry in high-elevation high tunnels. HortScience 45:1464-1469.

Siefker, J.H. and J.F. Hancock. 1986. Yield component interactions in cultivars of highbush blueberry. J. Amer. Soc. Hort. Sci. 111:606608.

Stafne, E. 2015. Fruit and nut review: Blueberries. Mississippi State Univ. Extension. Information Sheet 1448. 7 Sept. 2018. <https://extension. msstate.edu/sites/default/files/publications/ information-sheets/is1448_0.pdf>

Strik, B. 2014. Organic blueberry production systems -advances in research and industry. Acta Hort. 1017:257-267.

Strik, B.C., D.R. Bryla, and D.M. Sullivan. 2015 Organic blueberry production research project. Extension. 23 Aug. 2018. <https://articles. 
extension.org/pages/31680/organic-blueberryproduction-research-project $>$.

Strik, B.C., A. Vance, and D.R. Bryla. 2016. Organic production system research in blueberry and blackberry -a review of industrydriven studies. Acta Hort. 1117:139-148.

Strik, B.C., A. Vance, D.R. Bryla, and D.M. Sullivan. 2017. Organic production systems in northern highbush blueberry: I. Impact of planting method, cultivar, fertilizer, and mulch on yield and fruit quality from planting through maturity. HortScience 52:1201-1213.

Swain, P.A.W. and R.L. Darnell. 2002. Production systems influence source limitation to growth in 'Sharpblue' southern highbush blueberry. J. Amer. Soc. Hort. Sci. 127:409-414.

Univ. of California. 2012. Small Farm Program. Blueberries. 6 Sept. 2018. <http://sfp.ucdavis. edu/pubs/brochures/Blueberries_748/>.

U.S. Department of Agriculture, National Agricultural Statistics Service. 2015. Noncitrus fruits and nuts, 2014 preliminary summary. 7 Sept. 2018. <http://www.clientadvisoryservices.com/ Downloads/NoncFruiNu-01-23-2015.pdf>.

U.S. Department of Agriculture, National Agricultural Statistics Service. 2018. Noncitrus fruits and nuts 2017 summary. 24 Sept. 2018. <http://usda.mannlib.cornell.edu/usda/ current/NoncFruiNu/NoncFruiNu-06-26-2018.pdfs.

U.S. Department of Agriculture, National Resources Conservation Service. 2018. Report Generator 2.0. 9 Sept. 2018. <https:// wcc.sc.egov.usda.gov/reportGenerator/edit/ customMultiTimeSeriesGroupByStationReport/ daily/start_of_period/NONE/0,0/NONE? fitToScreen $=$ false $>$.

U.S. Highbush Blueberry Council. 2018. Where blueberries grow. 21 Aug. 2018. $<$ https://www. blueberrycouncil.org/growing-blueberries/ where-blueberries-grow/>.

Voogt, W., P. van Dijk, F. Douven, and R. van der Maas. 2014. Development of a soilless growing system for blueberries (Vaccinium corymbosum): Nutrient demand and nutrient solution. Acta Hort. 1017:215-221.

Weibel, F.P., R. Bickel, S. Leuthold, and T. Alfoldi. 2000. Are organically grown apples tastier and healthier? A comparative field study using conventional and alternative methods to measure fruit quality. Acta Hort. 517:417-426.
Wells, O.S. 1996. Rowcover and high tunnel growing systems in the United States. HortTechnology 6:172-176.

Whidden, A. 2008. Commercial blueberry production methods in Hillsborough county. Proc. Florida. State Hort. Soc. 121:36-37.

White, S.N., N.S. Boyd, and R.C. Van Acker. 2012. Growing degree-day models for predicting lowbush blueberry (Vaccinium angustifolium Ait.) ramet emergence, tip dieback, and flowering in Nova Scotia, Canada. HortScience 47:1014-1021.

Williamson, J.G., L. Mejia, B. Ferguson, P. Miller, and D.Z. Haman. 2015. Seasonal water use of southern highbush blueberry plants in subtropical climate. HortTechnology 25:185-191.

Yao, S. and C.J. Rosen. 2011. Primocane-fruiting raspberry production in high tunnels in a cold region of the upper Midwestern United States. HortTechnology 21:429-434.

Zhao, X., E.E. Carey, J.E. Young, W. Wang, and T. Iwamoto. 2007. Influences of organic fertilization, high tunnel environment, and postharvest storage on phenolic compounds in lettuce. HortScience 42:71-76. 